\title{
Hellige træer i hinduismen
}

\section{Et mødested imellem religionstyper}

\author{
MARIANNE QVORTRUP FIBIGER
}

\begin{abstract}
Der findes en guddommelig kraft $i$ træer, der gør det muligt for vand og energigivende stoffer/gødning at bevæge sig fra rødderne under jorden og op til træets krone, som går imod tyngdekraften. Det er ikke kun resultatet af kapillærernes arbejde (Keśakarșana), men af Krishna's kraft (Keśväkarșana). Krishna er $i$ træer. Den guddommelige kraft er $i$ alle planter. ${ }^{1}$
\end{abstract}

\begin{abstract}
ENGLISH ABSTRACT: In this article, the focus will be on the worship of tress in Hinduism in both a textual historical and a contemporary perspective. A main argument is that the worship of trees is a central part of most forms of Hinduism regardless of time and place, and also that it has contemporary and global appeal in the so-called eco-dharma movement.
\end{abstract}

DANSK RESUME: Denne artikel vil fokusere på tilbedelsen af træer $i$ hinduisme $i$ både et teksthistorisk og et nutidigt perspektiv. Et hovedargument er, at dyrkelsen eller tilbedelsen af træer er en central del af de fleste former for hinduisme uafhængigt af tid og sted, og også at det har nutidig og global appeal i en såkaldt øko-dharma bevægelse.

KEYWORDS: Hinduism; worship of trees; eco-dharma; bio-divinity

\section{Indledning}

Hinduismen er om nogen en akkumulerende religion. I stedet for at det gamle afløses af noget nyt, tilføjes det nye til det gamle; eller det gamle tolkes på en ny og anderledes måde, så det passer til en ny social, historisk evt. geografisk kontekst. Hinduismen lever med andre ord klart op til Robert Bellahs kendte dictum om, at "nothing is ever lost" (2011, 267). Det er der mange eksempler på; men i denne artikel vil jeg hævde, at et af de steder hvor dette forhold kommer tydeligst til udtryk, ${ }^{2}$ er i tilbedelsen af træer, og også i den betydning de tillægges.

1 Swadhyaya-bevægelsen citeret fra Jain 2019, 17, min oversættelse.

2 Her kunne selvfølgelig også nævnes tilbedelsen af floder og sekundært bjerge og dale. 
Det gælder både der, hvor de tillægges reel som symbolsk betydning, og, og ikke mindst, i krydsfeltet imellem de to felter. Fx er det tydeligt, hvordan træers betydning for menneskets overlevelse (giver skygge og ilt og er mad-, ilt- og brændselsproducerende) har indvirkning på den symbolske, indeksikale og ikoniske værdi, de samtidigt tillægges - $\mathrm{fx}$ at repræsentere en særlig guddom af navn eller at være en træguddom i sig selv, at bruges som kommunikationsled til en anden verden, at være oplysningssted, at være stedet hvor både det guddommelige og det dæmoniske har hvile, at være sandhedsvidne på indgåelse af traktater, og i moderne tid også at være det symbolske udtryk for at ville redde verden mod klimaforandringer etc. ${ }^{3}$

Dette krydsfelt imellem en reel til dels videnskabelig forklaring på træers betydning og en guddommelig, hvilket Emma Tomalin (2009) kalder bio-divinity i sin skitsering af hinduismens forhold til naturen, er også det, indledningscitatet indikerer. Det er hentet fra den nutidige hinduistiske Swadhyaya bevægelse; ${ }^{4}$ men jeg kunne have fundet tilsvarende eksempler mange andre steder fra. Ikke mindst i de upanishadiske tekster fra 6-300 f.v.t. bruges træet både symbolsk og indeksikalsk, og det samme kan man også se i nedenstående citat fra Bhagavadgitaen (200 f.v.t.-200 e.v.t.), hvor man fx i sang/kapitel 15 møder en forklaring på oprindelsen af såvel de hellige tekster, vedaerne, som på naturen og den menneskelig handling ved at pege på ashvatthatræet (også kendt som enten banyantræet, Ficus Benjamiona eller peepaltræet, Ficus Religiosa). ${ }^{5}$

Bhagavadgitaen foregår som en belærende dialog imellem Krishna (gud, guru og vognkusk) og Arjuna (discipel og kriger) og i det følgende er det Krishna, som taler. Han siger følgende:

1. De taler om det uforgængelige ashvattha-træ med rødderne opad og grenene nedad; dets blade er de vediske hymner. Den, som kender det, er veda-kyndig.

2. Dets grene strækker sig vidt nedad og opad og næres af gunaerne (naturen, prakritis

3 Og her trækker jeg på Charles Sanders Peirces (1839-1914) velkendte og brugbare tredeling af tegnet eller snarere repræsentamen for det, som skal repræsenteres: 1) Et ikon har en lighed med det, det repræsenterer. 2) Et indeks henviser til det, det skal repræsentere ved at skabe et kausalitetsforhold, eller en relation, fx at mørke skyer er tegn på regn. 3) Et symbol beror på en social konvention, hvor man ved en socialisering lærer at forbinde repræsentanten med det, der skal repræsenteres. Derfor indgår også det subjekt, for hvem tegnet/repræsentanten repræsenterer noget, og i den kontekst $\mathrm{i}$ hvilken denne relation befinder sig. Her er det fx vigtigt, at et træ kan være et træ i en sammenhæng og for nogle personer, men en repræsentant for noget andet $i$ en anden sammenhæng eller for andre personer.

4 Swadhyaya-bevægelsen, som har sit hovedsæde i Mumbai Maharashtra, er dog særlig interessant at trække frem. Det er en nutidig bevægelse, som har træ-tilbedelse som sit helt centrale omdrejningspunkt. Træet står i centrum i deres templer, da det anses som den stærkeste repræsentation eller manifestation af den guddommelige kraft - med reference til guden Krishna. Han anses som den endegyldige eller understøttende forklaring på, hvorfor naturen virker og er indrettet, som den er. Således trækker en ny bevægelse på gamle velkendte træk fra trætilbedelse i Indien.

5 Der er uenighed om ashvattha træet er et banyan eller et peepal-træ. Banyantræet er kendt for at have store luftrødder, som gør at træet ser ud som om det står omvendt; men hvis peepaltræet når en vis alder, vil også det sprede sig og udvikle luftrødder. 
grundbestanddele) med sanseobjekterne som dets knopskud; rødderne spreder sig også forneden og fremkalder handlen i menneskenes verden (Bhagavadgitaen kap 15, 1-2i Munk, Olesen og Pedersens oversættelse fra 2009 med mine uddybende tilføjelser i parentes).

Dette gensidigt begrundende vekselvirkningsforhold imellem en dennesidig og teknisk forklaringsmodel og en transcendent, som begge citater indikerer, kan man finde et utal af eksempler på op igennem den hinduistiske historie. Det kan man både, hvis man følger et historisk spor, der går helt tilbage til 3000 f.v.t. og til Indus- og adivasikulturen (oprindelige tribale folk), og også hvis man følger et andet og sandsynligvis sammenfaldende historisk spor, som begynder ved ariernes immigration fra omkring 1500 f.v.t. og frem til i dag. ${ }^{6}$

Tesen om, at "nothing is ever lost", kan også her bekræftes, hvis vi benytter os af et nutidigt synkront perspektiv, hvilket denne artikel også vil vise. Her kan vi på en og samme gang finde trædyrkelse i de små landsbyer, ved de store tempelkomplekser såvel som i guru-og asketbevægelserne og ikke mindst blandt nutidige bevægelser, der i den antropocæne tidsalder ${ }^{7}$ med store klimaforandringer til følge vender sig mod, hvad man kalder en øko-dharma.

Selvom der er stor forskel på, hvilken betydning træet tillægges, og på hvilken måde det indgår i et overordnet tolkningssystem eller ritualpraksis, er det et fællestræk, at natur og kultur ikke bliver tænkt som to adskilte størrelser. Det falder godt i tråd med Philippe Descolas karakteristik af den indiske ontologi (se fx s. 45) i hans bog: Beyond Nature and Culture (fransk 2005; engelsk 2013), hvor han netop betoner det svære ved at finde en adskillelse imellem det domesticerede og naturen i Kina, Japan og Indien.

Træer er et sådant mødested både imellem det domesticerede brugstræ og naturens vilde træ, men det er også mødested imellem verdener - denne og den anden, og mellem religionstyper både i et kulturevolutionistisk og i et nutidigt perspektiv. Nærværende artikel vil altså argumentere for, at træet er en uomgængelig faktor i stort set

6 I diskussionen om hinduismens historiske rødder kan der følges og argumenteres for flere forskellige spor. De to mest udbredte spor eller teser er henholdsvis kulturtransformationstesen og migrationstesen. Den første peger på, at hinduismen har rødder tilbage til Induskulturen, som forsvandt i 18-1700-tallet f.v.t. kombineret med eller efterfulgt af adivasiernes tribale religionsformer (adivasierne er en samlebetegnelse for et stort antal af små tribale samfund, der levede mere eller mindre isolereret rundt omkring i Indien). De talte bl.a. dravidisk. Migrationstesen refererer til arierne, som et nomadefolk, der vandrede ind i Nordindien fra omkring 1500-tallet f.v.t., og i denne tese argumenteres der for, at det er deres religionsform, der danner basis for hinduismen. En tredje tese, og som jeg selv hælder mest til, er interrelationstesen (bl.a. fremført af Wendy O'Doniger og Axel Michaels). Den betvivler ikke, at arierne kom udefra, men den understreger, at de gensidigt påvirkede og blev påvirket af dem, som allerede var i landet. Det er den tese, som også denne artikel bygger på ift. at finde spor i nutidig praksis fra både den tribale religionsform og fra det ariske tekstmateriale og deres institutionalisering af traditionen. Et kort, men godt overblik over denne diskussion hos Flood 1996, 27-35.

7 Den antroprocæne tidsalder er defineret ved, at menneskets aktiviteter påvirker jorden mere end de planetære kræfter, hvilket medfører klimaforandringer og ændrede migrationsstrømme. 
alle former for hinduistiske repræsentationer, og jeg vil begrunde det med historiske nedslag og med nutidige eksempler på trædyrkelse, lige fra den man finder i de små landsbyer på landet, ved de store tempelkomplekser i byerne eller ved særlige helligsteder, og til moderne guru- eller reform- genererede bevægelser. Eller for at blive i en Bellahsk terminologi, som den er udbygget og omformuleret af Hans J. Lundager Jensen (2020, 20-61): Trædyrkelse kan findes i tribale, arkaiske, aksiale, postaksiale, moderne og nutidige religionsformer. Hertil kan man tilføje en rearkaiseret religionsform (Fibiger, 2019). Mange af observationerne i det følgende bygger på mit eget feltarbejde.

For at kunne forstå træets betydning både i et diakront og synkront perspektiv vil jeg lige give en kort introduktion til de forskellige religionsformer. Meget kort fortalt kan man skelne imellem de følgende grundtyper: (1) Tribal religion er knyttet til små, spredte grupper, hvor religion, samfund og natur overordnet set forstås i en symbiotisk sammenhæng. Megen tribal religion er kendetegnet ved at have en animistisk ontologi, hvor alt egentlig er som mennesker indeni, men hvor ikke-menneskelige væsener har et anderledes ydre (som dyr, planter m.m.), hvilket styrer deres særlige adfærdsform. (2) Arkaisk religion er præget af en institutionalisering af religion med monumentale bygningsværker og en differentiering imellem religiøse eksperter og lægfolk. Religion bliver ofte tekstorienteret eller understøttet af tekst, når der udvikles skrift, ligesom ritualerne bliver kodificerede og ofte knyttet til en hellig institution. Man kan overordnet kalde arkaisk religion for velsignelsesreligion med en positiv indstilling over for verden. Guder som de dominerende andenverdensvæsener er ofte i centrum. (3) Aksial religion er individorientret og har fokus på frelse efter døden. Den er kendetegnet ved at være kritisk over for det bestående og denne verdens idealer, hvorfor målet er at befri sig fra denne verdens miserabilitet. Det betyder at askese og isolation er særligt typisk. Den kan overordnet kaldes en frelsesreligion. (4) Postaksial religion institutionaliserer det aksiale ideal og gør det derfor også tilgængeligt for en større gruppe af tilhængere. Visse religioner bliver til verdensreligioner, dvs. at religionerne bliver globale. Postaksialitet er også kendetegnende for dele af moderne religion. Verdensreligionerne tager ofte udgangspunkt i et aksialt ideal, men i en ny form, hvor der også finder en rearkarisering sted. (5) Nutidsreligion kommer forskelligt til udtryk forskellige steder i verden, men er overordnet set præget af øget globalisering, af sekularisering og religionskritik og ikke mindst ved en bekymring for fremtiden set i lyset af klimaforandringer, overbefolkning, pandemier o.l. Nutidsreligion kan også præges af rearkaisering, fx hvor arkaiske træk såsom pilgrimsfærd til hellige steder og processioner bliver relanceret i nutiden.

\section{Peepaltræet: et kort teksthistorisk overblik}

Særligt peepaltræet (Ficus religiosa), også kendt som bodhitræet (oplysningstræet), er sammen med banyantræet (Ficus Benjamiona) de to trætyper, som tilbedes mest i Indien: Peepaltræet bl.a. pga. sine hjerteformede blade og banyantræet pga. sine særlige luftrødder. Og begge træarter omkranses af et stort antal af mytologiske historier, som begrunder deres særlige egenskaber. 


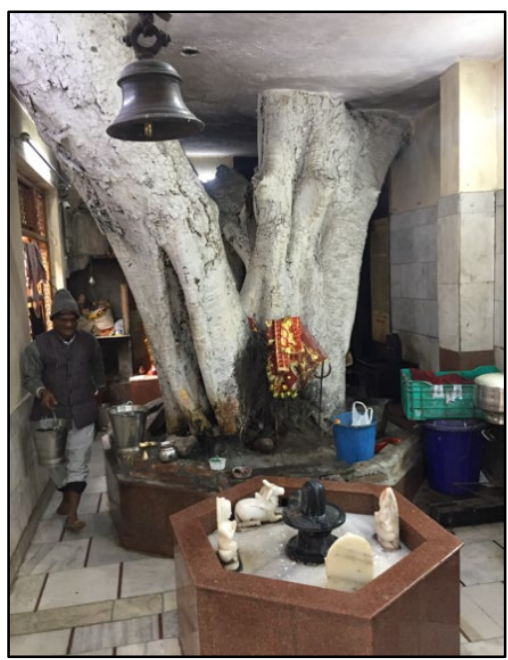

Figur 1 Billede fra et lille lokalt tempel midt $i$ New Delhi. Templet er bygget op omkring et stort peepaltræ, der er centrum for tilbedelsen. Her også som representant for Shiva. Foto: Marianne Qvortrup Fibiger, januar 2020.

Ser vi særligt på peepaltræet religionshistorisk, er der spor af peepal-trædyrkelse helt tilbage til induskulturen, da man har fundet segl afbildet med et peepaltræ ved de arkæologiske udgravninger som er foretaget af Mohenjo Daro, der udover Harappa var hovedsæde for Induskulturen. Seglene med peepaltræet er et godt udgangspunkt for at antage, at det dannede baggrund for en eller anden form for dyrkelse.

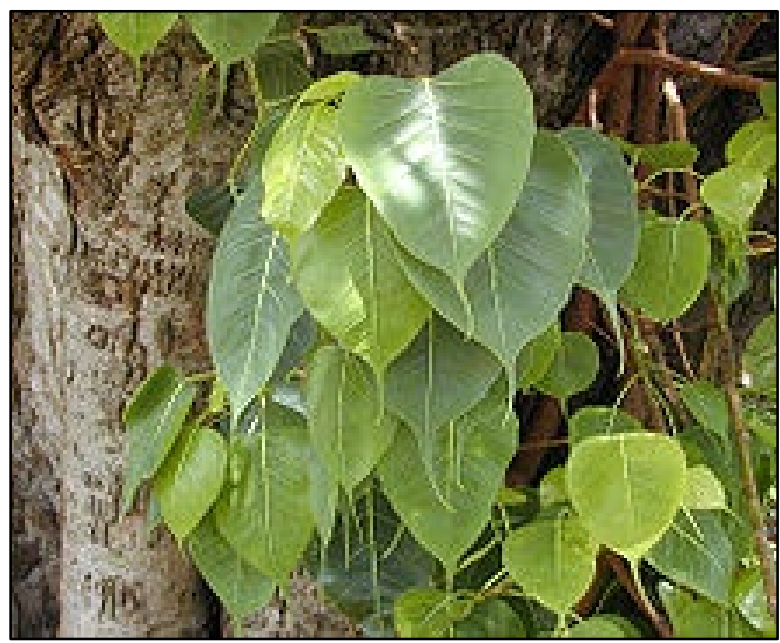

Figur 1. Peepaltræets hjerteformede blade, som ikke kun anses at have mindst 50 former for healende kvaliteter, de bruges også $i$ ritualer og som repræsentant for forskellige guddomme. https://en.wikipedia.org/wiki/File:Ficus_religiosa_Bo.jpg, set 2021.2.28) 


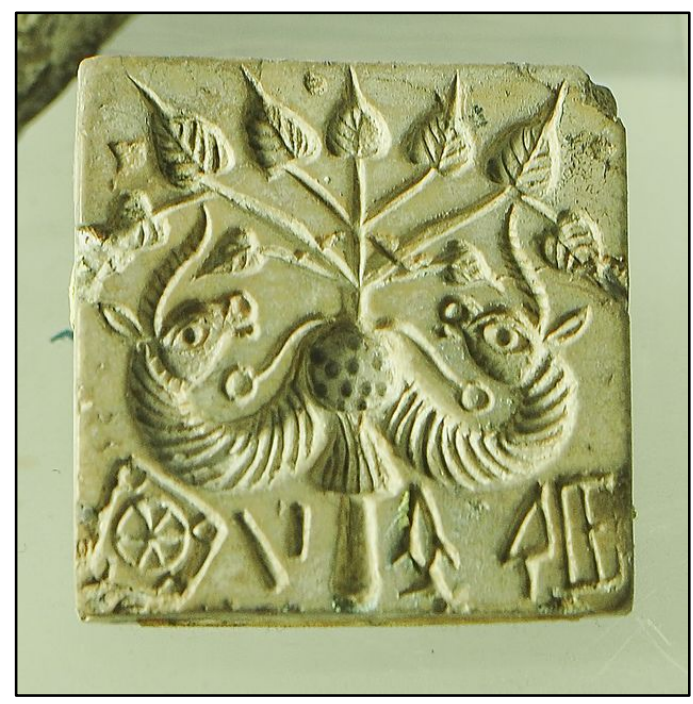

Figur 2. Segl fra Mohenjo Daro med et Peepaltræ omkranset af to monstrøse væsener, der mest af alt har enhjørningelignende træk.

Går vi til de første skriftlige kilder, kan vi allerede i Rigveda fra omkring 1200 f.v.t., finde mange eksempler på, hvordan peepaltræet synes at være et omdrejningspunkt for dele af kulten - både som en kommunikationsforbindelse til den anden verden, som baggrund for frugtbarhed og også som en repræsentant for guderne selv. Træet indgår derved i en prototypisk arkaisk religionsform. Et godt eksempel er følgende tekst fra Rigvedas 1. bog, hvor peepaltræet skildres som følger:

Indra siges at være træets stamme (stambha egentlig stolpe), som holder verdenerne adskilt fra hinanden. Guderne lever øverst på stolpen, mens mennesket og forfædrene forbliver i de nedre regioner.

Kommunikationen finder sted igennem/langs stolpen for det hellige offer er bundet til stolpen og derigennem distribueres det til guderne, og samtidig fungerer den som frugtbarhedsgiver, da den bringer de frugtbare vande til jorden (Sutherland 1991, 25, oversat af MQF.)

Går vi til upanishaderne, de yngste vediske skrifter, som repræsenterer et religionsskifte fra et arkaisk til et aksialt ideal, bevares træets betydning, selvom denne på flere felter forskydes. Træet bliver her både et meditativt redskab og et billede på, hvad der skal erkendes. Denne kombination bliver tydeligst udtrykt, hvor peepaltræet kaldes for et bodhi-træ (oplysningstræ), hvilket udvikler sig som et særligt træk ved buddhismen, der kan kaldes en prototypisk aksial religion. ${ }^{8}$ I det følgende lille tekststykke fra Katha Upanishaden kap. 6,1 bliver træet (her i form af et banyantræ) identificeret med

8 Ifølge Buddha-legenden var det under et bodhi-træ, at Buddha opnåede sin oplysning. Det betyder også, at bodhitræer er centrum for buddhistisk ritualpraksis i dag. Stort set ved alle de større buddhistiske templer i det nordlige Indien og i Sri Lanka vil man også kunne finde et bodhitræ, som lægfolk vandrer omkring i cirkumambulation, mens de vander træet. Disse bodhitræer siges at være aflæggere af det bodhi-træ, som Buddha fik sin oplysning under. På den måde skabes en taumaturgisk forbindelse imellem det legendariske 'urtræ' og alle andre bodhi-træer. Jf. Nugteren 2015. 
verdensaltet brahman, der er evig og udgangspunkt for alt det skabte, men som samtidig også står udenfor ved ikke at have fænomenologisk væren i sin reneste form. Eller sagt på en anden måde, sådan som det senere blev fremlagt af vedanta-filosofien: Brahman er både nir-guna (uden manifest form) og sa-guna (med manifest form). Det betyder, at brahman manifesterer sig i verden, så mennesket derigennem hjælpes til at erkende brahman uden form, hvorved mennesket kan frigøre sig fra tilknytning til den fænomenologiske verden.

Rødderne er for oven, grenene for neden; dette er det evige banyan-træ. Det er det klare, ${ }^{9}$ det er Brahman; det er det eneste som kan kaldes udødeligt. Alle verdener er placeret $\mathrm{i}$ det. Der er ikke noget ud over det (Katha Upanishad kap. 6.1 oversat af Patrick Olivelle 1996 og på dansk af MQF).

Hvad der ikke står i det lille tekststykke, men som er centralt for at forstå, hvordan træet kan indgå som fokuspunkt for asketens meditation, er, at en frigørelse for genfødslernes kredsløb og dermed en frigørelse fra denne verdens $d u k k h a$, 'lidelser' eller 'fortrædeligheder', er at erkende sit atmans (selv) identitet med brahman.

Et andet godt eksempel på brugen af træet som et indeksikalt tegn på det paradoksale ved altings udgangspunkt (brahman), som kan identificeres med atman, kan vi finde i Chandogya Upanishaden kap. 6,12,1-2. Her bruges dog banyantræets, og ikke peepaltræets frugter, som metaforisk billede. Vi befinder os midt i en typisk guru-elev belæring, hvor faderen, Aruni belærer sin søn Shvetaketu om atman-brahman-relationen med følgende belæring:

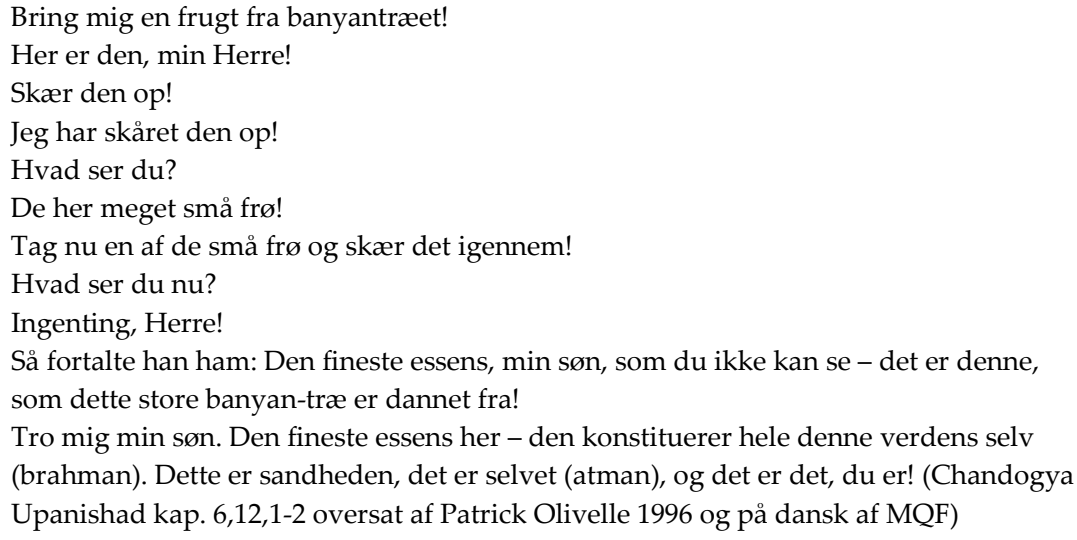

Bhagavadgitaen fra 200 f.v.t.-200 e.v.t. er en typisk postaksial tekst, som laver en syntesedannelse imellem det arkaiske vediske verdens- og menneskesyn koblet til det aksiale, bl.a. som vi møder det i upanishaderne. Bhagavadgitaen er samtidigt kritisk over for den vediske offerlære og også kritisk over for upanishaderenes asketiske ideal om at vende verden ryggen. Det særlige ved Bhagavadgitaen er, at den plæderer for et

9 På engelsk bright. Det kan dog oversættes med renhed, da det står i modsætning til grumset dvs. urent vand. 
yogisk ideal, som en form for skjold for denne verden, hvormed man dermed kan engagere sig i den: karma uden kama (handlinger uden begær eller tilknytning). Det er også det, det tidligere citerede stykke fra BG kap. 15 1-2 indikerer. Fortsættelsen i vers 3 viser dog endnu tydeligere en kritik af vedaernes offerlære og en vægt på det asketiske erkendelsesideal, hvor træet og det, det har genereret (vedaerne, almindelig menneskelig aktivitet) så at sige opløser sig selv og dermed sine verdsligt skabende egenskaber igennem erkendelse. Og træet viser sig i sin egentlige form, som vi kan læse i det følgende:

Dets form (træet) kan ikke ses således her i verden. Hverken dets ende, begyndelse eller beståen. Når dette ashvattha-træ med dets fuldvoksne rødder er fældet med afkaldets stærke økse (Bhagavadgitaen, 15,3 i Munk, Olesen og Pedersens oversættelse fra 2009 med min uddybende tilføjelse i parentes).

Et godt eksempel på en rearkaisering, men med tribale træk, er i den noget senere puranalitteratur fra mellem 450-1000 e.v.t., hvoraf langt de vigtigste er skrevet i slutningen af perioden. De er skrevet på de lokale sprog, så at alle, som kunne læse, havde adgang til dem. Religionshistorisk vil man også kalde perioden for en brahmaniseringsproces, hvor lokale traditioner og guder igennem helligskrifter inkorporeres i, hvad kan kaldes hinduistisk 'mainstream' eller den fælles kulturelle hukommelse.

I puranalitteraturen bliver et nyt gudepantheon introduceret. De tager, udover tekster som hylder gudinden, som den øverste guddom (Se fx Thomas B. Coburns oversættelse af Devimathmya purana) udgangspunkt i trimurti: de tre mandlige guder. Brahma, som skabergud, Vishnu og hans ti avataras (manifestationer) som opretholder af dharma og Shiva som den destruktive gud. Det er også disse guder med deres hustruer, som træerne i mange puranatekster repræsenterer. Enten som guderne selv, eller som deres bolig eller skjulested. Noget, som i min optik er en klar reminiscens fra den tribale religionsform, der altså inkorporeres ved at blive tekstliggjort. Det er også den forestilling, man primært støder på i de mange landsbyer i Indien i dag.

Jeg kunne have præsenteret et stort antal af puranaiske myter, hvor især Shiva og hans hustru Parvati og Vishnu eller en af hans avataras som fx Krishna og deres respektive hustruer eller elskerinder gemmer sig eller går i et med træerne. I stedet har jeg valgt følgende lille tekststykke fra Varaha-purana ${ }^{10}$ fra omkring 1000 e.v.t., som på en helt særlig måde understreger den betydning træet tillægges i purana-litteraturen, hvor det klart er velsignelsesaspektet og en denne-verdensorientering, som er i fokus:

De fem største begunstigelser som er givet os af træer, er som de fem mahayajnas ${ }^{11}$ (de fem store ofringer). De giver brændstof til familierne, skygge og hvilested for de rejsende,

10 Varaha betyder 'vildsvin' og refererer til en af Vishnus avataras (manifestationer), hvor han manifesterer sig i forskellige skikkelser for at bekæmpe antidharmiske kræfter. Det er altså primært en tekst, som dyrker Vishnu. Der er dog også afsnit, hvor både Shiva og også gudinden er i centrum. Særligt ved denne tekst er, at der er stor fokus på ritualer.

11 Der differentieres gerne imellem fem store ofringer, som et hushold bør udføre. De første fire hver dag, det femte, når der er tid, eller man har opnået et særligt livsstadium. Det er ofringer til guderne, til forfædrene til andre mennesker fx gæster og tiggere, til dyr og andre former for liv og det femte er til brahman. 
reder til fuglene, og medicin kommer fra deres blade, rødder og bark (Varaha Purana 162, 41-42 oversat af Iyer 1983 og på dansk af MQF.)

Denne beskrivelse ligger tæt op af de tekster som priser koen, som udgangspunkt for overlevelse. Fokus er altså tydeligt på denne verden, men især det sidste aspekt i.f.t. træets helbredende egenskaber er også noget, som der lægges særligt vægt på i moderne reform- og gurubevægelsers dyrkelse af træer og i den nye trend, nemlig økodharma, som er fremkommet i den antropocæne tidsalder. Purana-litteraturen og nutidig dyrkelse af træer er dog i mange tilfælde tæt sammenvævede, hvilket jeg vil vise i det følgende afsnit om nutidig lægmandsreligiøsitet knyttet til træer.

\section{Dyrkelsen af peepaltræet i et nutidigt perspektiv}

På mine snart mange feltrejser til Indien og til hinduer andre steder i verden har det altid slået mig, hvordan dyrkelsen af træer altid har været en helt central del af en hinduistisk lægmandspraksis. Der er i enhver landsby, og også gerne i de store byers gadehjørner træer, som tilbedes. Enten i sig selv, men ofte er der små gudestatuetter nedenfor placeret ved træets rødder, som også tilbedes. Den daglige tilbedelse (puja) foregår gerne hurtigt, $f x$ tændes et lys, nogle udfører en hurtig cirkumambulation, hvis det er muligt i.f.t. træets placering og andre smører lidt rødt kumkum-pulver eller gult sandeltræspulver på træets rødder eller på de små gudestatuetter ved træets rod. Det foregår ofte til eller fra arbejde eller i forbindelse med et andet gøremål. Vigtigt er det, at den enkelte kan udføre sin ofring til træet selv uden en præst som mellemled. Det er altså en ikke institutionaliseret religionsform.

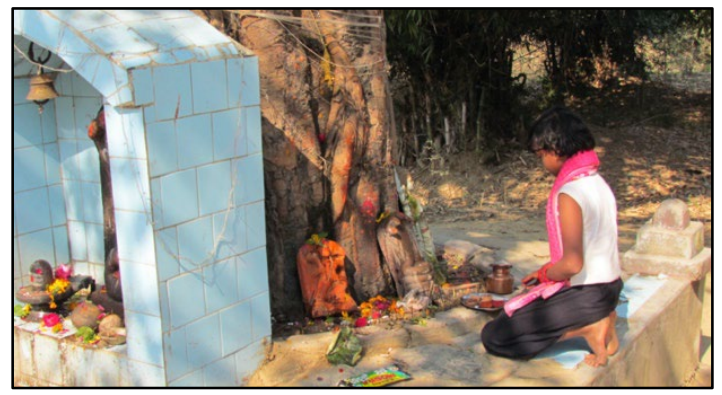

Figur 3. En pige udfører en kort puja (tilbedelse) på vej til skole (Foto: $M a$ rianne Q. Fibiger, Allahabad, 2013.)

Jeg har i mange tilfælde spurgt til den bagvedliggende forklaring, og jeg har fået stort lige så mange forskellige forklaringer, som dem jeg spørger. Der bliver dog især af de lokale præster refereret til mytologisk stof, gerne en purana. For lægfolk er det vigtigste, at de mener det virker, at deres bønner bliver hørt; men det er også vigtigt for dem, at de ved, at der er en eller anden begrundelse for, hvorfor det virker. Derfor er mytologi, fællesskabskonstituerende ritualer og en fælles hukommelse, indlejret i såvel tekst som krop, grundlæggende for at forstå den betydning træerne tillægges.

Dette er selvfølgelig koblet til et basalt ønske om overlevelse og at klare sig godt. Den følgende fremstilling vil derfor være en kombination af tekstreferencer og indlejret ritualpraksis, hvor kun dele af de mange forskellige typer kan blive præsenteret. 
Således håber jeg at give et lille indblik i træernes betydning, ikke mindst så det bliver tydeligt, hvordan netop forståelsen af træets iboende kraft, som jeg anser som et tribalt træk, både kombineres med en arkaisk religiøs pragmatik, og med anstrøg af et aksialt træk, da ritualerne i sidste ende også knyttes til et ønske om en bedre genfødsel og i sidste ende en frigørelse derfra. Meget af det følgende vil bygge på egne feltobservationer, hvorfor der ikke vil være så mange referencer til litteratur.

Der kan ikke tegnes et entydigt billede af træers tillagte betydning og den dertil knyttede ritualpraksis, da den er formet af den lokalitet, hvor trætilbedelsen finder sted. Fx er der forskel på, hvilken guddom(me) der er knyttet til de enkelte træer, afhængigt af om lokalområdet primært er med shaiva (shivadyrkere), vaishnava (vishnudyrkere) eller shaktas (gudindedyrkere). ${ }^{12}$

En udbredt ide er dog, at peepaltræet repræsenterer eller huser trimurti: Brahma, Vishnu og Shiva. Her bliver skaberguden Brahma oftest forbundet med træets rødder, stammen med den dharmaopretholdende Vishnu og bladene med Shiva, den destruktive gud, som destruerer det gamle (løvfald), for at noget nyt og bedre kan spire frem. Netop den sidste association betyder også, at peepaltræets blade ofte bruges som ofring i templer til netop Shiva. Udover trimurti dyrkes også devier (gudinder) og nagaen (kobraslangen) i sammenhæng med trætilbedelse.

Nagaen anses både som en frugtbarhedsgivende og destruktiv kraft, da den kan bide folk under markarbejdet. Det konstruktive knyttes til Shiva i form af frugtbarhed. Samtidigt repræsenterer slangen med sit hamskifte også genfødslernes kredsløb, og forbindes ofte med yogier og derfor et asketisk ideal, som igen peger hen på Shiva, der også afbildes som mediterende asket med en kobraslange om halsen. Så selvom det måske ikke kommer eksplicit til udtryk, og heller ikke er noget de fleste reflekterer over, ligger der implicit en reference til det asketiske ideal ved slangedyrkelsen. Særligt i Sydindien og i Sri Lanka ser man ofte små Naga-templer der, hvor to peepaltræers luftrødder slynger sig sammen.

12 Er man særligt interesseret i nordindisk trætilbedelse, vil jeg anbefale David L. Habermans bog People Trees. Tree worship in Northern India, 2013. 


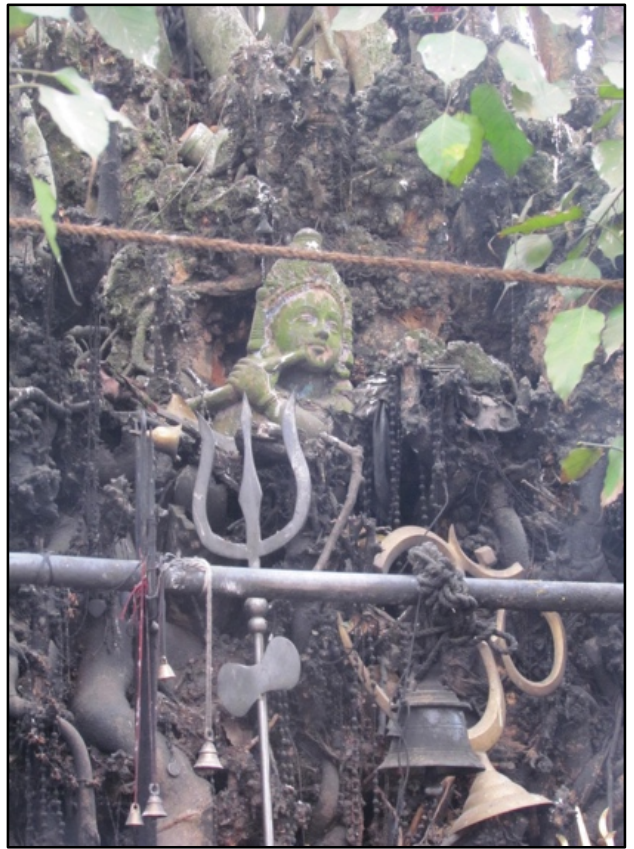

Figur 5. Peepaltræet dyrkes som trimurti, eller som repræsentant for en særlig guddom - her i form af Krishna, som er i træet. (Foto: Marianne Qvortrup Fibiger, Kerala, januar 2020).

Som nævnt findes der et stort antal af understøttende purana-tekster i.f.t. til trætilbedelse. Men idet purana-litteraturen med god ret kan siges at være påvirket af lokalt rodfæstede traditioner, er der også mange tribale træk i de mytologiske fortællinger, hvormed det nye gudepantheon (arkaisk træk) og trætilbedelse (tribalt træk) understøtter hinanden. Fx fortæller både Brahma purana og Padma purana, hvordan Vishnu gemte sig for dæmoner i et peepal-træ, før han endte med at bekæmpe dem. Derfor mener mange i dag, at det egentlig er Vishnu, man tilbeder, når træet tilbedes, selvom det i tribal sammenhæng vil være træet i sig selv, der tilbedes.

Tilsvarende forbindes Vishnus hustru Lakshmi særligt med peepaltræet om lørdagen, hvor hun menes at tage bolig i det. Og idet Lakshmi er lykkebringende, vil særligt kvinder, som endnu ikke har fået en søn, udføre en tråd-ceremoni, hvor de binder en rød tråd omkring træets stamme. Samtidigt beder de til gudinden, alias træet, om at skænke en søn. Det samme ritual, bare med en hvid tråd, udføres på særlige datoer på året, hvor kvinden ud over at faste også beder træets iboende guddom om, at hendes mand må få et godt og langt liv (se billedet nedenfor). En sidste trådceremoni, som er værd at nævne, er raksha bandhan ('knude for beskyttelse'). Det er et ritual, hvor bror og søster bindes symbolsk til hinanden med træet som sandhedsvidner. De vandrer sammen omkring træet og binder en tråd, som markerer, at broderen lover sin søster beskyttelse. Et stykke af samme tråd bindes om henholdsvis broderens og søsterens håndled. 


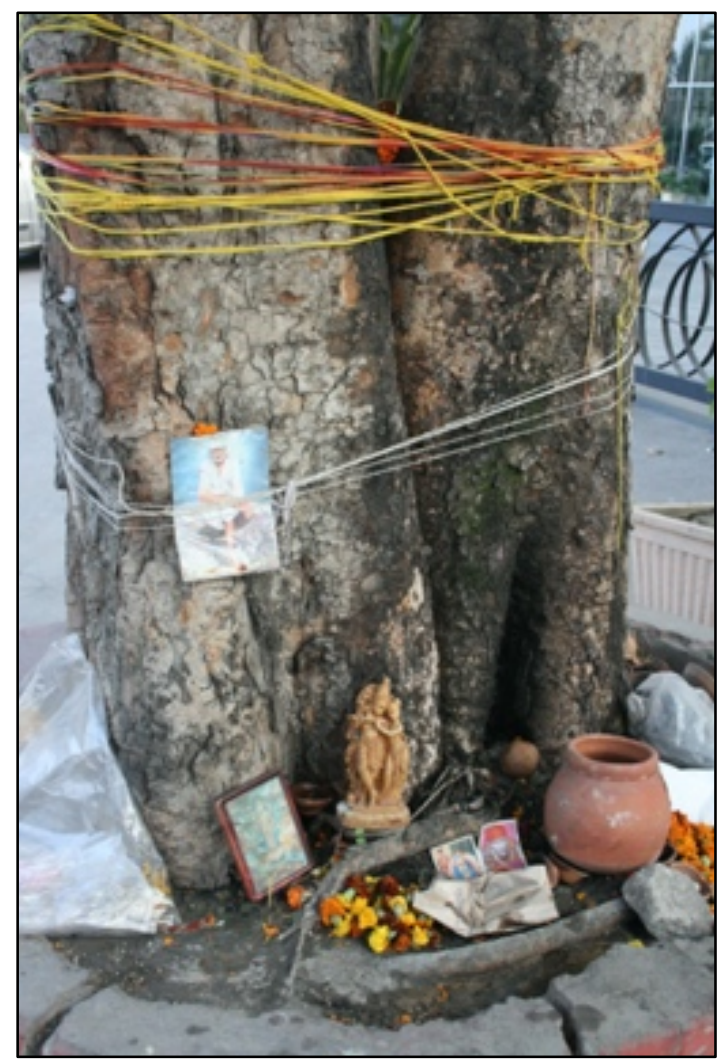

Figur 4. Peepaltræ i en sidegade $i$ Delhi, hoor flere former for trådceremonier har fundet sted. Samtidigt udgor træet et tempel bl.a. for Sai Baba dyrkelse. (Foto: Marianne Qvortrup Fibiger, januar 2020).

Der er et stort antal af andre historier, som begrunder træets betydning, eller som skaber en brobygning imellem et tribalt og et arkaisk ideal. Overtagelsen af træet som centrum for en gudedyrkelse eller med en større emfase på det arkaiske bliver dog tydeligt, der hvor træet knyttes til tempelinstitutionen. Her bliver træet også i form af brænde brugt i de store ildofringsritualer (homa eller havan), hvor røgen derfra udover at være kommunikationsled til gudernes verden også menes at rense såvel de lokale omgivelser som de tilstedeværendes sind.

Der står også gerne et peepal- eller et banyan træ i tempelgården (atrium), hvor den enkelte tilbeders egen puja kan foregå; men en puja kan også kodificeres og styres af tempelpersonalet under de større festivaler knyttet til templet. Her kan man fx nævne et særligt vuggeritual for guden Krishna som spædbarn, hvor Krishna vugges i søvn i templet. Det er samtidigt også det tidspunkt, hvor barnløse par hænger en vugge op i tempeltræet $\mathrm{i}$ håbet om, at de vil få et barn inden for den nærmeste fremtid. På den måde følger trætilbedelsen i højere grad den arkaisk funderede tempelpraksis end omvendt. 


\section{Dyrkelsen af træet i den antropocæne tidsalder}

Der findes et stort antal af reformbevægelser og guruorienterede bevægelser, der i større og større grad dyrker, hvad de kalder en øko-dharma. Her bliver den enkeltes levevis, etiske og moralske forpligtelse vendt mod naturbevarelse frem for den rolle, han eller hun måtte have over for $\mathrm{fx}$ sin familie set i sammenhæng med køn og livsstadium. Dette fokus ligger i ønsket om at dæmme op for nutidens store klimaforandringer. Det nye i denne øko-dharmiske naturbevidsthed er den stærke fokus på naturbevarelse, hvor det er bevarelsen af træet eller skovområder i sig selv, der bliver det afgørende, og ikke kun hvad træerne repræsenterer. ${ }^{13}$ Med andre ord bliver en overholdelse af dharma det samme som at sikre økosystemet. Dette appellerer ikke kun til hinduer, men til mange i det globale netværk, hvorved indiske hinduguruer får øget bevågenhed fra mange steder i verden.

En af disse globalt anerkendte eller tilbedte guruer er den kvindelige guru Amritanandamyi også kendt som 'Hugging Amma' fra Kerala, idet hun giver healende kram til alle, der kommer til hende. Hun har også med en 'plant et træ'kampagne en øko-profil, hvor hun på en overbevisende måde kobler træk fra den hinduistiske tradition til den øgede globale bekymring for klimaforandringerne betydning for fremtiden. Her er hinduismen som en akkumulerende tradition et fantastisk reservoir at hente fra til både at begrunde klimaforandringerne, og også til at finde på løsninger. Træet bliver også her på mange måder bragt i centrum. Teksten på dette billede er et godt eksempel på økodharma.

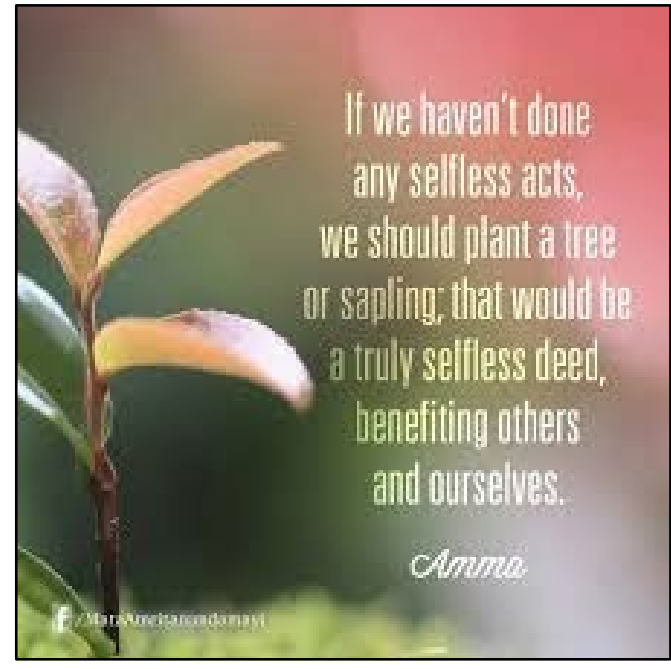

Hvordan Amritanandamayi kobler det tribale, det arkaiske og det aksiale ideal sammen i et øko-dharmisk budskab kan læses ud af følgende citat fra hende selv, som er gengivet i New Indian Express, fra d. 29.9.2019. Det er en journalist, som interviewer Amritanandamayi i forbindelse med en nyligt overstået darshan-turné ('at få et skue' og et kram af hende) rundt i Indien, og hun fortæller ham følgende historie derfra:

Once, while travelling through north India for the darshan programmes, we stopped at a pilgrim centre. There was a banyan tree under which a mahatma had attained enlightenment thousands of years ago. Hundreds of his devotees were there, circumambulating

13 For eksempel, og i modsætning til denne øko-dharmaiske orientering, konstaterede Rich Freeman (1999) under sit feltarbejde i Kerala i Sydindien, at selvom landsbybefolkningen tilbad de hellige lunde, var det guderne i dem og ikke lundene i sig selv, de tilbad. De var altså ikke miljøforkæmpere. 
the tree in reverence.

When the wind would blow the dry leaves from the tree, they would rush forward to collect them. When someone got a leaf, he would press it to his heart with devotion and carefully put it away to take back home.

Seeing their devotion, my eyes filled with tears because if only people could see every tree as divine like that sacred banyan, how much better the condition of our world would be. In truth, this would be enough (The New Indian Express, 29.9.2019).

\section{Konklusion}

Som de mange eksempler både i et historisk og et nutidigt perspektiv forhåbentlig viser, er trætilbedelse noget, der forener såvel forskellige religionstyper som elite og lægfolk inden for hinduisme. Træet bliver med andre ord et godt eksempel på hinduismens akkumulering af tradition, hvor der ikke kun bygges lag på lag, der trækkes også på et fælles symbolreservoir, som forener traditionen.

At træet tillægges forskellige betydninger, er sikkert; men det faktum, at træet som særlig genstand i ritualer og som særligt helligt symbol både i et diakront og i et synkront perspektiv kan være noget af det kit, som samler en tradition, der ellers er så svær at definere, sammen til en. Det interessante i en nutidig kontekst er, at træets symbolværdi koblet til en hinduistisk 'biodivinity', hvor natur og kultur kobles sammen, også har international appeal, hvilket øko-dharma i sin bredeste form viser. Her er netop trætilbedelse - som symbol på, at det er naturen, som vi skal have i centrum for vores tilbedelse og derfor værne særligt om - et godt brand verden over. Trætilbedelse synes altså både at kunne transcendere tid og sted og at have fundet endnu en betydningsdimension, som kan lægges til de mange tidligere.

\section{LITTERATUR}

\section{Bellah, Robert N.}

2011 Religion in Human Evolution. From the Paleolithic to the Axial Age, The Belknap Press of Harvard University Press. https://doi.org/10.4159/harvard.9780674063099

Coburn, Thomas B.

1991 Encountering the Goddess: a Translation of the Devi-mahatmya and a Study of Its Interpretation, State University of New York Press.

Descola, Philippe

2005 Beyond Nature and Culture, The University of Chicago Press.

Fibiger, Marianne Qvortrup

2019 "The Evolutionary Loop. Archaic Trends in Modern Time”, in: Klostergaard Petersen, Gilhus, Martin, Sinding Jensen \& Sørensen, eds., Evolution, Cognition and the History of Religion: A New Synthesis: Festschrift in Honour of Armin Geertz, Brill, 175-189. https://doi.org/10.1163/9789004385375_012

Flood, Gavin

1996 An introduction to Hinduism, Cambridge University Press. 


\section{Freeman, Rich J.}

1999 "Gods, Groves and the Culture of Nature in Kerala", Modern Asian Studies 33 (2), 257-302. https://doi.org/10.1017/S0026749X99003261

Haberman, David L.

2013 People Trees: Worship of Trees in Northern India, Oxford University Press. https://doi.org/10.1093/acprof:oso/9780199929177.001.0001

Iyer, S. V.

1983 The Varāha-Purāna, Part II. Translated and Annotated by S. V. Iyer, Motilal Barnasidass.

Jain, Pankaj

2019 Dharma and Ecology of Hindu Communities. Sustenance and Sustainability, Routledge.

Lundager Jensen, Hans J.

2020 "Religionshistorie et kort overblik", in: Marianne Qvortrup Fibiger \& idem, Andre verdener. Indføring i religionshistorie og religionsfanomenologi, Afdeling for Religionsvidenskab, Aarhus Universitet (print-on-demand): 11-63.

Michaels, Axel

2004 Hinduism. Past and Present, Princeton University Press.

Munk, Gitte, Bjarne W. Olesen \& Kristian Pedersen

2009 Bhagavadgītā, Ny dansk oversættelse, Forlaget Gammelmark.

Nugteren, Albertina

2015 "Rites of reverence, ways of worship: The bodhi tree in Bodhgaya as a material object and focus of devotion", in: Knut Jacobsen, Mikael Aktor \& Kristina Myrvold, eds., Objets of Worship in South Asian Religions, Routledge.

2018 "Sacred Trees, Groves, and Forests" In Oxford Bibliographies: https://www.oxfordbibliographies.com/view/document/obo9780195399318/obo-9780195399318-0192.xml (tilgået d. 15.3.2021)

Olivelle, Patrick

1996 Upanișads. A New Translation, Oxford University Press.

Sutherland, Gail Hinich

1991 The Disguises of the Demon: The Development of the Yaksa in Hinduism and Buddhism. SUNY Series in Hindu, Studies State University of New York Press. Tomalin, Emma

2009 Bio-Divinity and Bio-Diversity: The Limits to Religious Environmentalism, Ashgate.

\section{LINK:}

https://en.wikipedia.org/wiki/File:Ficus_religiosa_Bo.jpg (tilgået d. 28.2.2021)

Marianne Qvortrup Fibiger, lektor, ph.d. Afdeling for Religionsvidenskab, Aarhus Universitet 